Research Article

\title{
The Effect of Using Computer Simulation on Students' Performance in Teaching and Learning Physics: Are There Any Gender and Area Gaps?
}

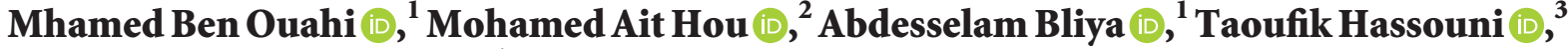 \\ and El Mehdi Al Ibrahmi ${ }^{1}{ }^{1}$ \\ ${ }^{1}$ Materials Physics and Subatomic Laboratory, Faculty of Science, Ibn Tofail University, Kenitra BP 133, Morocco \\ ${ }^{2}$ Department of Economic Sciences, Polydisciplinary Faculty of Errachidia, University of Moulay Ismail, \\ Errachidia BP 512, Morocco \\ ${ }^{3}$ Laboratory of Optoelectronic Physiochemistry of Materials and Environment, Faculty of Science, Ibn Tofail University, \\ Kenitra BP133, Morocco \\ Correspondence should be addressed to Mhamed Ben Ouahi; mhamed.benouahi@uit.ac.ma
}

Received 31 December 2020; Revised 5 March 2021; Accepted 10 March 2021; Published 23 March 2021

Academic Editor: Haoran Xie

Copyright (C) 2021 Mhamed Ben Ouahi et al. This is an open access article distributed under the Creative Commons Attribution License, which permits unrestricted use, distribution, and reproduction in any medium, provided the original work is properly cited.

\begin{abstract}
The aim of this study is to determine the effect of using computer simulation on students' performance in teaching and learning physical science, particularly the electrical Ohm's law. A sample of 182 students classified into two groups-experimental (92) and control (90)-from two middle schools in Meknes city (one in the rural area and the other urban area) was the subject of a pretest and posttest evaluation. The outcomes of the administered test to both groups of students, control and experimental, were compared and analyzed using Student's $t$-test and the Mann-Whitney $U$ test with Statistical Package for the Social Sciences (SPSS). The results obtained suggest that the experimental group register the best performances after the posttest than the control group $(p<0.05)$. While no difference, in terms of performance, was signed according to gender in the experimental group $(p>0.05)$, the urban students were more successful than the rural ones, with and without the use of simulations. In this respect, this study recommended using and practicing simulation software to improve and develop the performance of middle school students.
\end{abstract}

\section{Introduction}

The most important thing in science education is the practical side and hands-on training, especially in secondary schools, where the students gradually begin to embody their learning and use their observation skills, analysis, and conclusion. There are different ways, methods, and strategies of science teaching due to the accumulation of information and the increase and complexity of knowledge; it has appeared urgent to find a style or method to simplify and facilitate the transfer of information in the minds of students.

With scientific development and technological revolution, computer simulation technology and the use of its models such as virtual reality, artificial intelligence, and others have arisen, and the need to take advantage of it to develop education and solve its problems and serve the learner and the teacher is already reflected in the improvement of the efficiency of the educational process [1].

Educational computer simulation programs are considered to be one of the best and most powerful educational computer programs when used in science education if properly programmed. It is based on the principle of constructivist philosophy, which emphasizes that the student learns through scientific experience; these are also computer-generated dynamic models, which can explain the concept or simplified model of a component, of a phenomenon or conceptual process in the real world, consisting 
of animation, visualization, and interactive laboratory experiences [2].

The uses of computer simulations can activate multiple skills in science learners such as observing, measuring, predicting, controlling variables, formulating hypotheses, and interpreting results $[1,3]$. It allows learners to explicitly develop metacognition and allows them to reflect on their learning [1], improve motivation and interest in the class [4], and to present itself as an effective prediction tool [5]. One method has shown that nonverbal representations stimulate brain activity [6]. Simulation can multiply the forms of representation (images, animations, graphics, and digital data). By allowing the learner to choose the representations he prefers, this allows him to individualize learning, increase his motivation, and follow in the footsteps of learners throughout their learning [7].

Many science researchers attempt to answer such a question through studies that focus on the effects of computer simulations on students' understanding of science concepts as well as on motivation. These researchers studied the effectiveness of computer simulations from different points of view. Some researchers have studied the efficiency of computer simulations compared to the traditional method [8-10], and some have used simulations to improve the efficiency of traditional methods [11] as well as to effectively improve students' understanding of the difficult concept instead of the traditional method [12]. Other researchers have used simulations as prelaboratory activities to improve the efficiency of laboratory equipment $[4,13,14]$, while some have studied whether computer simulations can replace real equipment $[15,16]$.

1.1. Statement of the Problem. The teaching of science in Moroccan middle schools suffers from many problems, including the curriculum, the students, the teaching methods used, the availability of tools, materials, teaching techniques, and the school environment.

Studies conducted by $[17,18]$ show that there is a low performance of students in science in general and in physical science in particular, in different stages of education. In addition, the results of the survey TIMSS 2019 (Trends in International Mathematics and Science Study) [19], which measures science and mathematics proficiency among primary and middle school students, place Morocco among the last countries in terms of students' aptitude in mathematics and science, but only slightly ahead of 2015 [20], and at the bottom of the OECD survey (L' Organization for Economic Cooperation and Development) [21] with regard to the general performance in reading, science, mathematics, and girls' performance is better than boys in science, and also, the school performance of rural students is low compared to urban ones. Another research indicates that science education in Morocco faces several challenges such as the poor performance of students in physical sciences [22]. As a result, a change should be made in the mechanisms that deal with the curriculum, in particular in the presentation of educational content and teaching methods, as the provision of content in accordance with educational programs, including computerized programs and the use of modern teaching strategies including interactive computer simulations PhET (Physics Education Technology) which was developed by the University of Colorado at Boulder [23]. The use of PhET simulation is important to improve students' understanding and motivation in learning about "electrical resistance and the Ohm's law" "electricity."

PhET interactive simulations transfer the learner from the passive recipient of the material to the role of interacting with him, enhance his learning [24], which will shift the role of the teacher from the vector information in a rigid format to students in order to memorize them and recall them during the examination to an interactive teacher in a learning environment that allows the learner to follow their learning step by step, and is responsible for providing simple activities and situations closest to reality, thanks to the computerization of the material.

Although some research studies have covered the topic of PhET interactive computer simulations and their impact on success, these studies have not given sufficient interest to study PhET techniques among third-year middle school students, particularly in Moroccan schools, and their impact on academic success in rural areas.

This research is a study in which rural and urban students use interactive computer simulation to overcome some of the difficulties associated with the concept of "electrical resistance and the Ohm's Law," and to improve their scientific understanding and motivation, interactive simulations are used for the experimental group, while the control group followed the lesson under traditional conditions to compare their effects with the effects of interactive simulations on the realization. Finally, the study aims to analyze the effects of interactive simulations on the academic performance of third year students.

1.2. Research Questions. Based on this aim of the study, the following research questions were identified:

(1) Is there a significant statistical difference in students' performance, as measured by the pretest and posttest scores, between students taught through computer simulations and those taught traditionally

(2) Is there a significant statistical difference between the performance of males and females in the two groups (experimental and control), according to pretest scores of the students

(3) Is there a significant statistical difference between the performance of males and females in the experimental group, according to posttest scores of the students

(4) Is there a significant statistical difference between the performance of rural and urban area students, according to pretest and posttest scores of the students

\section{Materials and Methods}

2.1. Ethical Considerations. Before the study, we informed the students that the lesson would be conducted in an 
academic environment that took ethical principles into account. Students are free to attend the lesson during which the activity is carried out. In addition, it is announced that the data collected may be shared in a scientific journal. However, according to correspondence sent by the Ministry of National Education to school principals, the taking of photos of students is subject to prior authorization from their parents. Therefore, students are informed that no visuals will be used in the study and that they are not actually used.

2.2. Study Design. To assess the impact of the use of simulation on student learning, a semiexperimental design with a pretest and a posttest was used. We used 6 classes in this study to create 2 groups, where 3 classes as a control group and 3 classes as an experimental group. The choice of these two groups picked randomly was made from 6 different classes of 3rd year middle school, from two Moroccan schools in the city of Meknes, Zaitoune and El Yasmine middle schools.

In the experimental group, students learned with simulation PhET (Physics Education Technology) entitled "Ohm's Law," while students in the control group learned the conventional method using the multimedia product.

2.3. The Target Population. The target population for this study was composed of 182 students in 3rd middle school (males: 93 and females: 89 ) who were at two middle schools in the province of Meknes during the spring semester of the 2018-2019 school year, as illustrated in Tables 1 and 2.

2.3.1. Distribution of Students by Gender and the Method Used. From the results in Table 1, we see that among the total number of pupils taken by the study, there are 49 male pupils who were the subject of the traditional method (that is, $26.9 \%$ of the total), whereas 44 are the subject to the experimental method (24.2\%). For female students, there are 41 students who used the traditional method (22.5\%) and 48 students who used the experimental method (26.4\%).

2.3.2. Distribution of Students by Gender and Area. The results in Table 1 show that out of a total of 182 pupils concerned by the study, there are 93 male pupils (51.1\%) of whom 60 follow their studies in the rural or semirural (33\%) and 33 are studying in the urban environment (18.1\%). Concerning female students, there are 89 students ( $48.9 \%$ of the total), of which 58 students follow their studies in rural or semirural areas (31.9\%) and 31 study in urban areas (i.e., $17 \%)$.

2.3.3. Distribution of Students by the Study Area and Method Used. The results in Table 2 show that among the 182 pupils studied, there are, respectively, 59 pupils from rural areas (i.e., 32.4\%) and 31 pupils from urban areas (i.e., 17\%) who are used for the traditional method. Also, 59 (32.4\%) students were from the rural area and 33 (18.1\%) students from the urban area, respectively, have undergone the experimental test method.

2.4. Research Instruments. The study data were collected using a performance test (pretest/posttest). The pretest assessed the prior knowledge of learners in both groups on the topic of electricity and consisted of 5 closed-ended questions with one choice and 3 closed-ended questions. The posttest was used to determine the effect of the use of the computer simulation on the learners' performance and consisted of 5 closed-ended questions with a one-choice answer and 3 closed-ended questions. After the advice of two teachers and a pedagogical physics inspector with long experience in secondary education and the necessary modifications, the performance test was carried out with 34 students to examine the reliability of the test items.

Cronbach's alpha value was calculated (pretest, 0.780; posttest, 0.708 ), which allowed us to apply the test items to both groups before and after the implementation of the study.

2.5. Research Procedure and Data Analysis. We applied a pretest to learners in both groups before the study began. After that, the experimental group was taught using simulation activities for four hours over two weeks for each class. The simulation is a flash animation that allows students to follow the plotting of characteristics during the study of Ohm's law (measurements, choice of units, scales, placement of points, plotting of characteristics, and formulation of the law of proportionality); it is from PhET (Physics Education Technology) group at the University of Colorado at Boulder taken from http://phet.colorado.edu/sims/cck/cck-dc.jnlp. Screenshots of the simulation are shown in Figure 1. The control group used a multimedia product when learning about the same subject with the experimental group. Due to the lack of computers, we divided the students into groups of three members per computer (the computer room contains 10 computers) with a sheet (practical work-Ohm's law simulation). A video projector connected to the teacher's computer was used in parallel to support and guide the students in the construction of their knowledge and to answer any technical questions. After completing the study process, we distributed the posttest material to two groups.

The data collected were analyzed using IBM SPSS (Statistical Package for the Social Sciences) version 23. Descriptive statistics (minimum, maximum, mean, and standard deviations) and inferential statistics (Student's $t$ test and Mann-Whitney nonparametric $U$ test) were used to analyses the data. All the results were interpreted at $p<0.05$.

\section{Results and Discussion}

Our main objective is to study the impact of simulation interactive on student learning. To achieve this, we first analyzed and compared the results of the pretest according to gender, area, and the adopted method. Second, we compared the posttest results according to gender, area, and the adopted method. All analyses were performed using 
TABLE 1: Distribution of students by gender according to area and the method used.

\begin{tabular}{|c|c|c|c|c|c|c|c|}
\hline & & & Traditional & Experimental & Rural & Urban & Total \\
\hline \multirow{4}{*}{ Gender } & \multirow{2}{*}{ M } & Effective & 49 & 44 & 60 & 33 & 93 \\
\hline & & $\%$ of the total & $26.9 \%$ & $24.2 \%$ & $33.0 \%$ & $18.1 \%$ & $51.1 \%$ \\
\hline & \multirow{2}{*}{$\mathrm{F}$} & Effective & 41 & 48 & 58 & 31 & 89 \\
\hline & & $\%$ of the total & $22.5 \%$ & $26.4 \%$ & $31.9 \%$ & $17.0 \%$ & $48.9 \%$ \\
\hline \multirow{2}{*}{ Total } & & Effective & 90 & 92 & 118 & 64 & 182 \\
\hline & & $\%$ of the total & $49.5 \%$ & $50.5 \%$ & $64.8 \%$ & $35.2 \%$ & $100.0 \%$ \\
\hline
\end{tabular}

TABle 2: Distribution of students by the study area and method used.

\begin{tabular}{|c|c|c|c|c|c|}
\hline & & & Traditional & Experimental & Total \\
\hline \multirow{4}{*}{ Area } & \multirow{2}{*}{ Rural } & Effective & 59 & 59 & 118 \\
\hline & & $\%$ of the total & $32.4 \%$ & $32.4 \%$ & $64.8 \%$ \\
\hline & \multirow{2}{*}{ Urban } & Effective & 31 & 33 & 64 \\
\hline & & $\%$ of the total & $17.0 \%$ & $18.1 \%$ & $35.2 \%$ \\
\hline \multirow{2}{*}{ Total } & & Effective & 90 & 92 & 182 \\
\hline & & $\%$ of the total & $49.5 \%$ & $50.5 \%$ & $100.0 \%$ \\
\hline
\end{tabular}

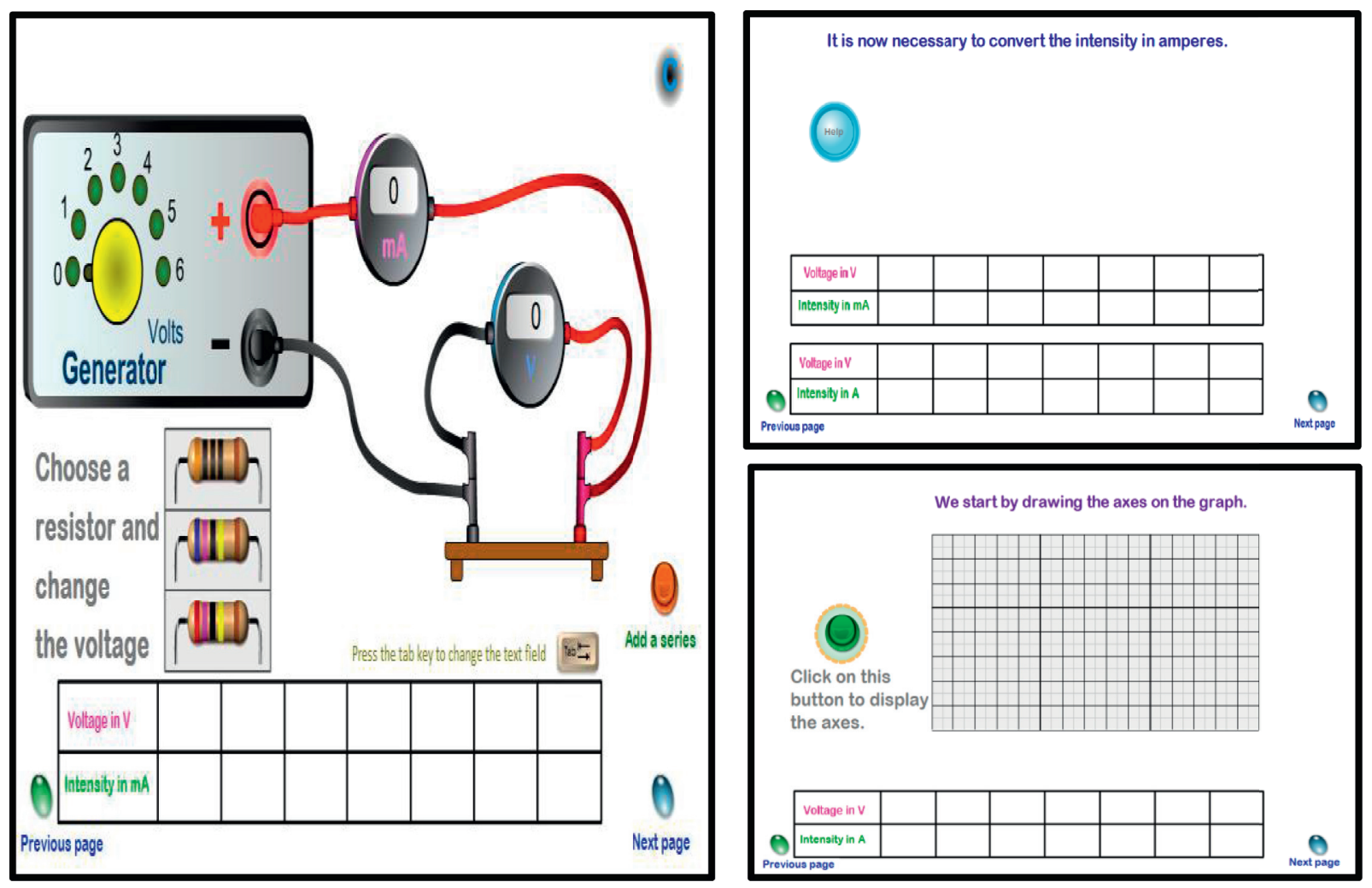

FIGURE 1: The screenshots of simulation.

SPSS Statistics 23 to calculate the average value, medians, and standard deviations.

In this study, to measure the distribution of the data, the method used is the Kolmogorov-Smirnov method because the number of samples is $\geq 25$. The data are called as normal distribution if the Kolmogorov-Smirnov value is $\geq$ the significant value $(0.05)$. The results of the normal distribution in both groups (control and experimental) are presented in two tables (Tables 3 and 4).
The $p$ value of Kolmogorov-Smirnov in the experimental group is $0.001 \leq$ significant value 0.05 (has no normalized distribution), while the control group is $0.158 \geq$ significant value 0.05 (the distribution is normalized). Because one of the groups does not have a normal population distribution, we used the Mann-Whitney $U$ test to compare the results.

The Kolmogorov-Smirnov $p$ value of the sex is $F=0.013$ and $M=0.10$, and the Kolmogorov-Smirnov value of the 
TABLE 3: Tests of normality of the pretest according to the method, gender, and area.

\begin{tabular}{|c|c|c|c|c|}
\hline \multicolumn{5}{|c|}{ Kolmogorov-Smirnov $^{\mathrm{a}}$} \\
\hline & & Statistic & df & Sig. \\
\hline \multirow{2}{*}{ Method used } & Traditional & 0.084 & 90 & 0.158 \\
\hline & Experimental & 0.127 & 92 & 0.001 \\
\hline \multirow{2}{*}{ Gender } & $\mathrm{M}$ & 0.107 & 93 & 0.010 \\
\hline & $\mathrm{F}$ & 0.108 & 89 & 0.013 \\
\hline \multirow{2}{*}{ Area } & Rural & 0.117 & 118 & 0.000 \\
\hline & Urban & 0.088 & 64 & $0.200 *$ \\
\hline
\end{tabular}

${ }^{*}$ This is a lower bound of the true significance. ${ }^{\text {a }}$ Lilliefors significance correction

TABLE 4: Tests of normality of the posttest according to the method, gender (pilot), and area (pilot).

\begin{tabular}{lcccc}
\hline & \multicolumn{2}{c}{ Kolmogorov-Smirnov $^{\mathrm{a}}$} & & \\
& & Statistic & df & Sig. \\
\hline \multirow{2}{*}{ Method used } & Traditional & 0.117 & 90 & 0.004 \\
& Experimental & 0.100 & 92 & 0.023 \\
Gender (pilot) & $\mathrm{M}$ & 0.112 & 44 & $0.200^{*}$ \\
& $\mathrm{~F}$ & 0.095 & 48 & $0.200^{*}$ \\
Area (pilot) & Rural & 0.092 & 59 & $0.200^{*}$ \\
& Urban & 0.147 & 33 & 0.068 \\
\hline
\end{tabular}

${ }^{*}$ This is a lower bound of the true significance. ${ }^{\text {a }}$ Lilliefors significance correction

area is rural $=0.000$ and urban $=0.200$; there is no normal distribution, so the Mann-Whitney method will be used.

Table 4 shows that the Kolmogorov-Smirnov $p$ value of the method used is traditional $=0.004$ and experimental $=0.023$; in this case, the distribution of values does not follow the normal distribution because the Kolmogorov-Smirnov $p$ value is $\leq$ the alpha level $(0,05)$. Therefore, the method that will be used is the Mann-Whitney method.

However, the $p$ value of Kolmogorov-Smirnov of gender (pilot) and area (pilot) is $\geq 0.05$. In this case, we will use the method of $t$-test students.

3.1. Results and Discussion of the Diagnostic Test. In order to give meaning to the results of the study, we will first try to compare the means of the students, subject of the study, according to gender, environment, and the method used. The results obtained are reported in Table 5 .

\subsubsection{Students' Performances in the Diagnostic Test according} to the Method Used. The distribution of the means of the two middle schools in the pilot group and the control is shown in Figure 2.

The results of the experimental group show that $33.7 \%$ of the students had scores below $8 / 20$, and only $34.78 \%$ achieved satisfactory results (score is above $12 / 20$ ), with an observed average of order of 11.05/20. The same trend was recorded in the control group (frequency of grades [0, 8 [,] $12,20]$ are $32.22 \%$ and $33.33 \%$, respectively, with an observed average 10.66/20). In terms of knowledge, both groups have very little knowledge about Ohm's law, as the average score of both groups does not exceed 12. On the other hand, since no student has an average score of 0.00 , it can mean that all students have basic knowledge of Ohm's law. Perhaps, this is because many students have studied electrical resistance in the second year middle school.

Table 5 shows that the two groups have the same median values and that the students' means of the experimental group in the pretest is $m=11.05(\sigma=4.40)$ which is higher than the general average $m=10.86$ while that of the control group students is $m=10.66(\sigma=3.98)$ below the general average. The calculation of the variation coefficients of the two groups shows that the scores of the control group are rather dispersed (coefficient of variation, $\mathrm{CV}=39.83 \%$ ) compared to the scores of the control group $(\mathrm{CV}=37.31 \%)$.

To test whether this difference is significant and to accept the hypothesis that no significant difference existed between the two groups at the time of the pretest, we used the Mann-Whitney $U$ test (in this case, the distribution of the values does not follow the normal distribution because the $p$ value of Kolmogorov-Smirnov is lower than the chosen alpha level). The results of the comparison are presented in Table 6 (pretest according to the method).

For the Mann-Whitney test, certain norms are used as a basis for the decision-making hypotheses. The Man$\mathrm{n}$-Whitney test norms are as follows: if Asymp. Sig. (2tailed) $\leq 0.05$, then $\mathrm{Ha}$ is accepted. If Asymp. Sig. (2 tails) $\geq$ 0.05 , then Ha is rejected. Based on Table 6, the result showed that Asymp. Sig. (2-tailed) is $p=0.665>0.05$. It can be concluded that hypothesis Ha was rejected for the Man$\mathrm{n}$-Whitney test. It can therefore be said that there is no significant difference between the groups (control and experimental). This implies that the two groups had the same level of knowledge, which is explained by the use of the complete system of school management "MASSAR," which already ensures the equivalence repartition between the groups during the constitution of the classes. This result allows us to validate our experimental model based on a pretest and a posttest.

3.1.2. Students' Performances in the Diagnostic Test according to Gender. From the results in Table 5, it can be seen, on the one hand, that the general average is around 10.86 with a standard deviation of around 4.19. The calculation of the coefficient of variation (CV) shows that the scores are moderately dispersed around the mean $(\mathrm{CV} \approx 0.387$ or $38.7 \%)$. On the other hand, the median grade is 10.00 . In other words, $50 \%$ of the students have a grade higher than 10.00 , and the remaining $50 \%$ have a grade lower than ten $(<10.00)$. More importantly, Table 5 shows that boys have an average equal to 10.05 which is lower than the general average, while girls have an average (11.70) higher than the general average. The calculation of the variation coefficients of the two genders shows that the scores of boys are rather dispersed $(\mathrm{CV}=40.43 \%)$ compared to the scores of girls $(\mathrm{CV}=35.7 \%)$.

Despite these results, it cannot be confirmed that there is a statistical difference between males and females in terms of 
TABle 5: Means of the diagnostic test by the gender, area, and method used.

\begin{tabular}{lcccccrr}
\hline & & Average & $N$ & Standard deviation & Median & Low & Max. \\
\hline \multirow{2}{*}{ Gender } & $\mathrm{M}$ & 10.05 & 93 & 4.06 & 9.00 & 1.50 & 20.00 \\
& $\mathrm{~F}$ & 11.70 & 89 & 118 & 3.86 & 11.00 & 3.00 \\
Area & Rural & 9.82 & 12.77 & 64 & 4.14 & 20.00 \\
& Urban & 10.66 & 90 & 3.98 & 12.50 & 1.50 & 18.50 \\
Method & Traditional & 11.05 & 92 & 4.40 & 10.00 & 1.50 & 20.00 \\
& Experimental & 10.86 & 182 & 4.19 & 10.00 & 3.00 & 20.00 \\
Total & & & & & 10.00 & 1.50 \\
\hline
\end{tabular}

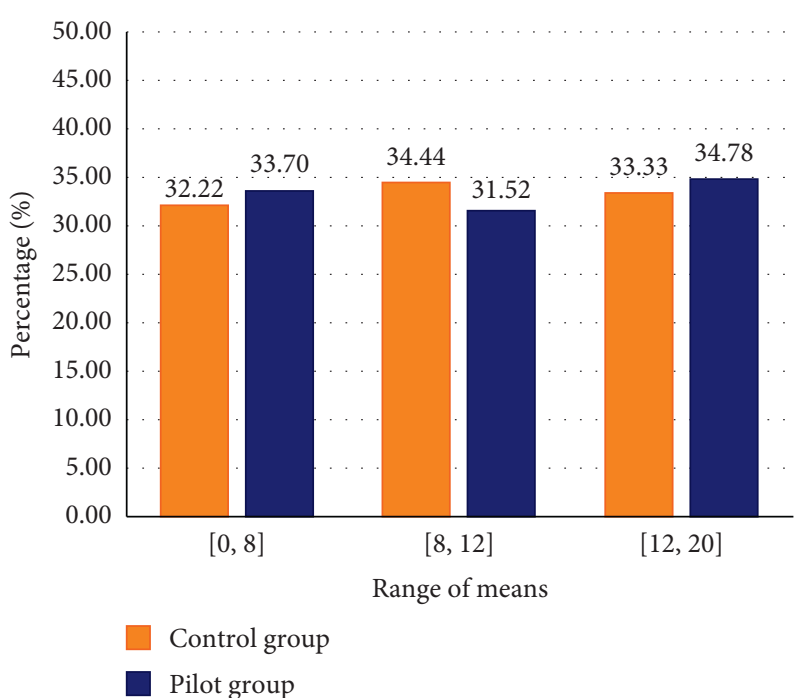

Figure 2: Distribution of means of diagnostic test results in the pilot and control groups.

TABLE 6: Mann-Whitney test for independent samples (pretest) according to the method, gender, and area.

\begin{tabular}{lccc}
\hline & Pretest according to the method used & Pretest by gender & Pretest according to the area \\
\hline Mann-Whitney $U$ & 3986,500 & 3148,000 & 2285,500 \\
Wilcoxon W & 8081,500 & 7519,000 & 9306,500 \\
Z & -0.432 & -2.791 & -4.397 \\
Asymp. Sig. (2-tailed) & 0.665 & 0.005 & 0.000 \\
\hline
\end{tabular}

performance. And for this, we used the Mann-Whitney test to compare the means of the two independent samples. A level of significance $\alpha$ of $0.05(\alpha=5 \%)$ was used for interpreting the results which are presented in Table 6 (pretest by gender).

According to Table 6, the Asymp. Sig. (2-tailed) is $p=$ $0.005<0.05$ which is significant. It can be said that there is a significant difference between boys and girls in the diagnostic test (pretest). Girls are therefore more efficient than boys. This is because girls are more attentive in class, more focused, and more disciplined at work, while boys are more focused on games than girls, spend less time on study, and less disciplined. Because of this behavior, girls score better in Morocco as well as in many other countries than boys. These results are consistent with the TIMSS study (2015), concerning student performance by gender in science, and also, it is in high agreement with the study released by [25].
3.1.3. Students' Performances in the Diagnostic Test according to the Area. Table 5 shows that students in rural areas and students in urban ones do not have the same medians: the median in the urban area (12.50) is higher to that in the rural area (9.00). The standard deviation of the results in the rural area is slightly lower than that in the urban area. So, we can consider that the pupils of the two zones do not have the same strength. That is, there is a more marked difference between the results of students in the two zones (rural $\mathrm{CV}=39 \%$ and urban $\mathrm{CV}=32 \%$ ).

In order to test the importance of the difference between the mean scores, the Mann-Whitney $U$ test of independent samples was used, and the results are presented in Table 6 above (pretest according to the area) (Asymp. Sig. (2-tailed) is $0.000<0.05$ ) which confirms that the average of students in urban areas was significantly higher than that of students in rural ones. This result can be explained by the determinants linked to the socioeconomic situation of the parents. 
TABLE 7: Means of the evaluation test according to the gender (pilot), area (pilot), and method used.

\begin{tabular}{|c|c|c|c|c|c|c|c|}
\hline & & Average & $N$ & Standard deviation & Median & Low & Max. \\
\hline \multirow{2}{*}{ Gender } & M & 12.20 & 44 & 3.83 & 12.00 & 4.00 & 20.00 \\
\hline & F & 11.82 & 48 & 3.93 & 11.50 & 6.00 & 20.00 \\
\hline \multirow{2}{*}{ Area } & Rural & 11.18 & 59 & 3.77 & 11.00 & 4.00 & 20.00 \\
\hline & Urban & 13.48 & 33 & 3.63 & 14.00 & 6.00 & 20.00 \\
\hline \multirow{2}{*}{ Method } & Traditional & 10.09 & 90 & 3.10 & 10.00 & 3.00 & 20.00 \\
\hline & Experimental & 12.01 & 92 & 3.87 & 12.00 & 4.00 & 20.00 \\
\hline Total & & 11.06 & 182 & 3.63 & 11.00 & 3.00 & 20.00 \\
\hline
\end{tabular}

Most of the students from rural areas in our case are coming from poor families and helping their parents, without forgetting the school context and the family context in which most parents have low educational levels, and also, the school environment in rural areas influences their performance. This result is in agreement with the study of [26]. Also, the authors found the negative impact of the pupil's occupation (pupil work in crafts or agriculture) on school performance, and this can be explained by the health problems which can generate, especially work in the field of crafts.

3.2. Results and Discussion of the Posttest. The posttest results that were obtained were analyzed statistically using SPSS software and are reported in Table 7.

3.2.1. Students' Performances in the Posttest according to the Method Used. The posttest correction in the two groups made it possible to obtain the results represented by the graph as shown in Figure 3. We emphasize that these results are expressed in terms of percentage of correct answers.

According to these results, the majority of the students in the pilot group (82\%) belong to the class whose marks are higher than $8 / 20$, while the majority of the students in the control group (37\%) have achieved marks lower than $8 / 20$. Almost, the same frequency of means $[8,12]$ was recorded in both groups (almost 40\%).

Table 7 shows that the average of the students in the experimental group in the posttest is average (av) $=12.01$ $(\sigma=3.863)$ while that of the students in the control group is av $=10.09(\sigma=3.0)$; the difference is 1.92 , and also, the two groups do not have the same median values. Despite the difference observed in the means obtained according to various previous analyzes, it cannot be confirmed whether there is a significant difference between the compared groups or not. In order to make sense of these results, the Mann-Whitney $U$ test of independent samples was used. The results of the comparison are reported in Table 8 (posttest according to the method).

The analysis of the results (Table 8) shows that Asymp. Sig. (2-tailed) is $p=0.001$ which is less than 0.05 . We can conclude that hypothesis Ha is accepted for Mann-Whitney. As a result, it can be said that there is a significant difference in favor of the experimental group in the posttest. This result indicates that the experimental group is more efficient than the control group, which is due to the teaching of scientific materials for the benefit of students in a modern way that

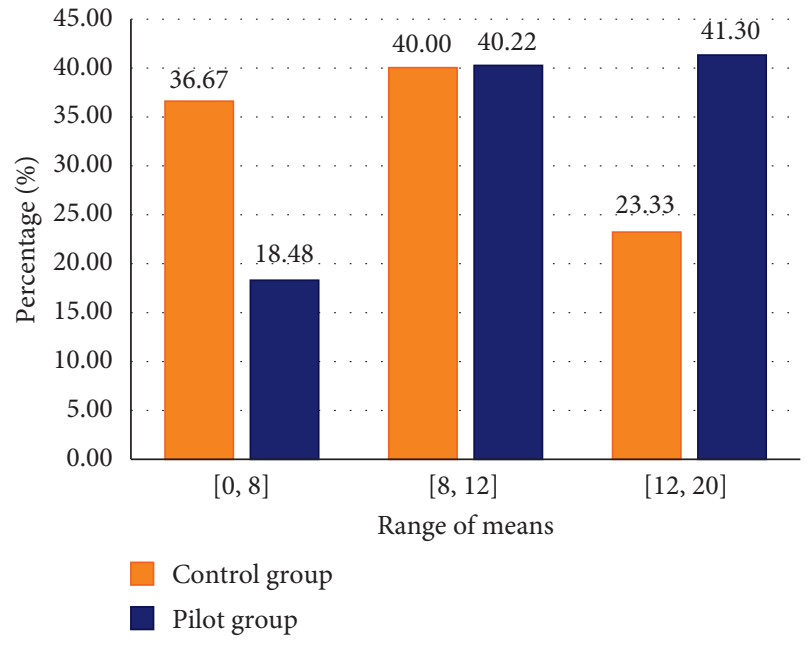

FIgURE 3: Distribution of the means of the posttest results in the pilot group and the control group.

TABLE 8: Mann-Whitney test for the independent samples posttest according to the method used.

\begin{tabular}{lc}
\hline & Posttest according to the method used \\
\hline Mann-Whitney $U$ & 2936,500 \\
Wilcoxon W & 7031,500 \\
Z & -3.403 \\
Asymp. Sig. (2-tailed) & 0.001 \\
\hline
\end{tabular}

contains multimedia that simulates reality and helps students to understand physical terms and difficult concepts, and it makes the process of learning physics, especially the part of electricity, easy and pleasant, while it allows students to change the variables of experience and get the desired result with ease and without fear or hesitation or even the timidity of the rest of their classmates. It also works to consider individual difference.

This method emphasized the role of students in autonomy which helped their self-confidence. The latest had a clear impact on improving the learning outcome. This outcome agreed with the result of the study [27] which stressed that physics simulations offer interactive learning opportunities for learners in this subject. Simulations of physics experiments stimulate more meaning. They improve student motivation and make lessons more interesting, focus their attention on learning, provide beautiful diagrams, and enjoy when doing simulations on computers. This can be 
TABLe 9: The $t$-test of independent samples (posttest) according to the method, gender (pilot), and the area (pilot).

\begin{tabular}{|c|c|c|c|c|c|c|c|c|c|c|}
\hline & & \multicolumn{4}{|c|}{$\begin{array}{c}\text { Levene's test for equality of } \\
\text { variances }\end{array}$} & \multicolumn{5}{|c|}{$t$-test for equality of means } \\
\hline & & $\mathrm{F}$ & Sig. & $t$ & $\mathrm{df}$ & $\begin{array}{c}\text { Sig. } \\
\text { (2-tailed) }\end{array}$ & $\begin{array}{c}\text { Mean } \\
\text { difference }\end{array}$ & $\begin{array}{l}\text { Std. error } \\
\text { difference }\end{array}$ & $\begin{array}{r}9 \\
\text { confi } \\
\text { interva } \\
\text { diffe }\end{array}$ & $\begin{array}{l}\text { dence } \\
1 \text { of the } \\
\text { rence }\end{array}$ \\
\hline & & & & & & & & & Lower & Upper \\
\hline \multirow{2}{*}{$\begin{array}{l}\text { Posttest by gender } \\
\text { (pilot) }\end{array}$} & $\begin{array}{c}\text { Equal variances } \\
\text { assumed }\end{array}$ & 0.040 & 0.841 & 0.471 & 90 & 0.639 & 0.382 & 0.810 & -1.227 & 1.990 \\
\hline & $\begin{array}{c}\text { Equal variances not } \\
\text { assumed }\end{array}$ & & & 0.472 & 89.666 & 0.638 & 0.382 & 0.809 & -1.225 & 1.989 \\
\hline \multirow{2}{*}{$\begin{array}{l}\text { Posttest according to the } \\
\text { area (pilot) }\end{array}$} & $\begin{array}{c}\text { Equal variances } \\
\text { assumed }\end{array}$ & 0.023 & 0.880 & -2.853 & 90 & 0.005 & -2.307 & 0.809 & -3.913 & -0.700 \\
\hline & $\begin{array}{c}\text { Equal variances not } \\
\text { assumed }\end{array}$ & & & -2.883 & 68.429 & 0.005 & -2.307 & 0.800 & -3.904 & -0.710 \\
\hline
\end{tabular}

attributed to the facilitation and simplification of physical concepts that almost need to be made easy for improving the students' thought processes. This had a positive influence on the acquisition and storage of information. The result of the present study was approved with the result of the studies $[28,29]$, as well as with the result of the study [30]. Other surveys [31, 32] have shown that the use of computer simulations had a positive effect on student results which are in line with our results. However, a recent study shows that there was no significant difference in scientific success between the traditional practical method and the computeraided simulation method [33]; this inconsistency may be due to the type of concepts taught, to the type of simulation used, to the intervention of foreign variables, to the size of the sample, and to the different models used, and this does not prove that the computer simulation method is not feasible and effective in the educational process because the results of most studies that have compared between the computer simulation and the ordinary teaching methods indicate the advantage of the computer simulation method.

3.2.2. Students' Performances in the Posttest according to Gender of the Experimental Group. Table 7 shows that girls have an average equal to 11.82 which is lower than the general average, while boys have an average (12.20) higher than the general average. The calculation of the variation coefficients of both males and females shows that the girls' scores are rather dispersed $(\mathrm{CV}=33.24 \%)$ compared to the boys' scores $(\mathrm{CV}=31.35 \%)$. Despite these results, it cannot be confirmed that there is a significant statistical difference between the two sexes in terms of performance. To test the significant difference between the means of two independent samples having a normal distribution (Table 4), we used the $t$-test of the students. The results are presented in Table 9 (posttest by gender pilot).

Table 9 results show that there is no significant difference between girls and boys if the computer simulations were used in the experimental group $(t=0.471$ and $p$ value $0.639>0.05)$. Thus, this suggests that computer simulations do not discriminate against the sexes. Our results are supported by the findings of Sentongo and Stern [30, 34].
3.2.3. Students' Performances of the Experimental Group in the Posttest according to the Area. Table 7 shows that students in rural areas and students in urban ones do not have the same medians: the median for urban area students (14.00) is higher than that in rural area ones (11.00). The standard deviation for the urban area students is slightly lower than that for the rural area students. The calculation of the variation coefficients in the two zones shows that the scores for the rural area students are rather dispersed $(\mathrm{CV}=33.7 \%)$ compared to the scores for the urban area students $(\mathrm{CV}=26.7 \%)$. Despite the differences observed, we cannot confirm whether there is a significant difference between the urban and rural areas or not. So, we have to use the $t$-test technique for independent samples (having a normal distribution) as shown in Table 9. Table 9 (posttest according to the area pilot) provides that the $p$ test value is $p=0.005<0.05$ which is significant. This result allows us to conclude that there is a significant difference between the students of two zones who use the simulation. Students in urban areas, therefore, appear to perform better than students in rural ones. This is due to the fact that urban area students perform better than rural area ones because they have more or less easy access to the computer tool and to the Internet connection through libraries, cultural centers, centers of support, and cyber cafés, while rural area students face many difficulties such as living far from school, power outages, almost complete lack of Internet connection, and lack of transportation. All these factors have a remarkable impact on the students' learning process.

\section{Conclusion}

This study attempted to identify the impact of the use of computer simulations on learning middle school in the provincial directorate of education, Meknes. The sample for this study was selected from public schools where computers are available to apply the experiment. Statistical data collected from the semiexperimental research using a pretest and a posttest with an experimental group and a control group showed that students in the experimental group who were taught using simulations were more successful than the 
group students who were taught by the traditional approach. Furthermore, there was no difference between the results of boys and girls in the experimental group, which suggests that computer simulations do not discriminate against the sexes and that the results of students in the rural areas are slightly lower than those of urban students with or without the use of computer simulators.

At the end of this research, we can say that the chosen simulation had a positive impact on the performance of the students in the experimental group and refined their understanding (a cognitive process essential for improving skills application) and therefore enabled them to overcome certain learning difficulties.

\section{Data Availability}

The data used to support the findings of this study are available from the corresponding author upon request.

\section{Conflicts of Interest}

The authors declare that there are no conflicts of interest.

\section{Acknowledgments}

The authors would like to thank teachers and students who participated in this work and thank Physics Education Technology (PhET) group from the University of Colorado at Boulder for allowing them to use the simulation freely.

\section{References}

[1] M. Droui and A. El Hajjami, "Simulations informatiques en enseignement des sciences: apports et limites," Epinet Rev. Électronique L'EPI, pp. 1-17, 2014, http://www.epi.asso.fr/ revue/articles/a1404e.htm.

[2] R. L. Bell and L. K. Smetana, "Using computer simulations to enhance science teaching and learning," Technology Secondary Science Classroom, National Science Teaching Association, vol. 3, pp. 23-32, 2008.

[3] K. Mahdi, J.-I. Laafou, and R. Mohamed, "The impact of continuous distance training on teachers of physics in computer simulation software," Journal for Educators, Teachers and Trainers, vol. 9, no. 1, pp. 27-41, 2018, http:// www.ugr.es/ jett/index.php.

[4] P. Martinez-Jimenez, A. Pontes-Pedrajas, J. Polo, and M. S. Climent-Bellido, "Learning in chemistry with virtual laboratories," Journal of Chemical Education, vol. 80, no. 3, pp. 346-352, 2003.

[5] D. R. Lavoie and R. Good, "The nature and use of prediction skills in a biological computer simulation," Journal of Research in Science Teaching, vol. 25, no. 5, pp. 335-360, 1988.

[6] D. H. Clements and S. McMillen, "Rethinking "concrete" manipulatives," Teaching Children Mathematics, vol. 2, no. 5, pp. 270-279, 1996, https://www.jstor.org/stable/41196500.

[7] P. Cholmsky, "Why gizmos work: empirical evidence for the instructional effectiveness of explore learning's interactive content," Charlottesville Virginia Official Explorer, vol. 15, p. 2006, 2003.

[8] C.-H. Chen and B. Howard, "Effect of live simulation on middle school students' attitudes and learning toward science," Journal of Educational Technology \& Society, vol. 13, no. 1, pp. 133-139, 2010.

[9] C. Bayrak, "Effects of computer simulations programs on university students' achievments in physics," Turkish Online Journal of Distance Education, vol. 9, no. 4, pp. 53-62, 2008.

[10] U. Sari and G. B. Güven, "The effect of interactive whiteboard supported inquiry-based learning on achievement and motivation in physics and views of prospective teachers toward the instruction," Necatibey Faculty of Education, Electronic Journal of Science Mathematics Education, vol. 7, no. 2, 2013.

[11] A. Jimoyiannis and V. Komis, "Computer simulations in physics teaching and learning: a case study on students' understanding of trajectory motion," Computers \& Education, vol. 36, no. 2, pp. 183-204, 2001.

[12] A. A. Yas, M. N. Ahmed, and T. A.-E. Tala, "Effects of using simulation in e-learning programs on misconceptions and motivations towards learning," International Journal of Science and Technology Education Research, vol. 5, no. 3, pp. 40-51, 2014.

[13] Z. C. Zacharia, "Comparing and combining real and virtual experimentation: an effort to enhance students' conceptual understanding of electric circuits," Journal of Computer Assisted Learning, vol. 23, no. 2, pp. 120-132, 2007.

[14] U. Sarı, Ş. Ulukök, and F. Z. Özdemir, "The effect of virtual laboratory applications for "Electricity in our life" unit on science process skills and attitudes," Mediterranean Journal of Educational Research, vol. 14, pp. 650-655, 2013.

[15] N. D. Finkelstein, K. K. Perkins, W. Adams, P. Kohl, and N. Podolefsky, "Can computer simulations replace real equipment in undergraduate laboratories?” AIP Conference Proceedings, vol. 790, pp. 101-104, 2005.

[16] Z. K. Unlu and I. Dokme, "The effect of combining analogybased simulation and laboratory activities on Turkish elementary school students' understanding of simple electric circuits," Turkish Online Journal of Educational Technology, vol. 10, no. 4, pp. 320-329, 2011.

[17] N. Nasser, M. El Khouzai, and M. Taoufik, "Difficultés d'apprentissage des sciences physiques chez les élèves du secondaire qualifiant au Maroc," American Journal of Innovative Research \& Applied Sciences, vol. 5, no. 2, pp. 119-125, 2017, https://american-jiras.com/Naoual-ManuscriptRef.1ajira250617.pdf.

[18] M. Chekour, M. Laafou, and R. Janati-Idrissi, "Les facteurs influençant l'acquisition des concepts en électricité," Cas des lycéens marocains Adjectif En Ligne, http://www.adjectif.net/ spip/spip.php?article354, 2015.

[19] M. O. Martin, D. L. Kelly, and B. Fishbein, “TIMSS 2019 international results in mathematics and science," 2019, https://timss2019.org/reports/.

[20] M. Stephens, K. Landeros, R. Perkins, and J. H. Tang, "Highlights from TIMSS and TIMSS Advanced 2015: mathematics and science achievement of U.S. students in grades 4 and 8 and in advanced courses at the end of high school in an international context," in Proceedings of the NCES 2017-002, Chestnut Hill, MA, USA, November 2016, https://nces.ed. gov/pubs2017/2017002.pdf.

[21] Andreas Schleicher, "PISA 2018 insights and interpretations," 2018, https://www.oecd.org/pisa/PISA/2018/Insights/and/ Interpretations/FINAL/PDF.pdf.

[22] INESEFRS, Programme national d'évaluation des acquis des élèves du tronc commun, Le Conseil Supérieur de l'Education, de la Formation et de la Recherche Scientifique, Rabat, Morocco, 2016, https://www.csefrs.ma/wp-content/uploads/ 2017/02/Rapport-methodologie-Final.pdf. 
[23] K. Perkins, E. Moore, N. Podolefsky et al., "Towards researchbased strategies for using PhET simulations in middle school physical science classes," AIP Conference Proceedings, vol. 1413, pp. 295-298, 2012.

[24] N. Rutten, W. R. Van Joolingen, and J. T. Van Der Veen, “The learning effects of computer simulations in science education," Computers \& Education, vol. 58, no. 1, pp. 136-153, 2012.

[25] M.-L. Fu, L. Cheng, S.-H. Tu, and W.-H. Pan, "Association between unhealthful eating patterns and unfavorable overall school performance in children," Journal of the American Dietetic Association, vol. 107, no. 11, pp. 1935-1943, 2007.

[26] K. Ateilah, Y. Aboussaleh, and A. Ahami, "Les déterminants socioéconomiques et démographiques des faibles performances scolaires des élèves dans un collège rural la région de Sidi Taybi Kenitra (Maroc)," Antropo, vol. 26, pp. 83-89, 2012, http://www.didac.ehu.es/antropo/39/39-06/Ateillah.pdf.

[27] T. Civelek, E. Ucar, and O. Gokcol, "Cyprus international conference on educational research the effects of computer asssited simulations of physics experiments on learning," Procedia - Social and Behavioral Sciences, vol. 47, pp. 17801786, 2012.

[28] C. Tsihouridis, D. Vavougios, and G. S. Ioannidis, "The effectiveness of virtual laboratories as a contemporary teaching tool in the teaching of electric circuits in Upper High School as compared to that of real labs," International Conference on Interactive Collaborative Learning (ICL), vol. 2013, pp. 816$820,2013$.

[29] R. Shegog, M. M. Lazarus, N. G. Murray, P. M. Diamond, N. Sessions, and E. Zsigmond, "Virtual transgenics: using a molecular biology simulation to impact student academic achievement and attitudes," Research in Science Education, vol. 42, no. 5, pp. 875-890, 2012.

[30] J. Sentongo, R. Kyakulaga, and I. Kibirige, "The effect of using computer simulations in teaching chemical bonding: experiences with ugandan learners," International Journal of Educational Sciences, vol. 5, no. 4, pp. 433-441, 2013.

[31] Y. Nafidi, A. Alami, Z. Moncef, B. El Batri, and H. Afkar, "Impacts of the use of a digital simulation in learning earth sciences (the case of relative dating in high school)," Journal of Turkish Science Education, vol. 15, no. 1, pp. 89-108, 2018, https://www.tused.org/index.php/tused/article/view/151.

[32] D. D. Kumar, P. V. Thomas, J. D. Morris, K. M. Tobias, M. Baker, and T. Jermanovich, "Effect of current electricity simulation supported learning on the conceptual understanding of elementary and secondary teachers," Journal of Science Education and Technology, vol. 20, no. 2, pp. 111-115, 2011.

[33] S. L. Hannel and J. Cuevas, "A study on science achievement and motivation using computer-based simulations compared to traditional hands-on manipulation," Georgia Educational Researcher, vol. 15, no. 1, 1 page, 2018.

[34] L. Stern, N. Barnea, and S. Shauli, "The effect of a computerized simulation on middle school students' understanding of the kinetic molecular theory," Journal of Science Education and Technology, vol. 17, no. 4, pp. 305-315, 2008. 